\title{
BMP3 wt Allele
}

National Cancer Institute

\section{Source}

National Cancer Institute. BMP3 wt Allele. NCI Thesaurus. Code C51530.

Human BMP3 wild-type allele is located within 4p14-q21 and is approximately $23 \mathrm{~kb}$ in length. This allele, which encodes bone morphogenetic protein 3 , plays a role in serine/threonine kinase signal transduction and the induction of bone formation. 